\title{
SEVERITY OF DIABETIC RETINOPATHY IN RELATION WITH HEMOGLOBIN A1C AND SERUM LIPIDS
}

Tariq Qureshi, Rashid Maqbool, Nausheen Abdullah,Rahila Ramzan, Anjum Fazili.

1. Associate Professor. Department of Ophthalmology, Govt. Medical College, Srinagar, Kashmir.

2. Post Graduate. Department of Ophthalmology, Govt. Medical College, Srinagar, Kashmir.

3. Senior Resident. Department of Ophthalmology, Govt. Medical College, Srinagar, Kashmir.

4. Senior Resident. Department of Ophthalmology, Govt. Medical College, Srinagar, Kashmir.

5. Associate Professor. Department of Community Medicine, SKIMS, Srinagar, Kashmir.

\section{CORRESPONDING AUTHOR:}

Dr. Tariq Qureshi,

Associate Professor,

Postgraduate, Department of Ophthalmology,

Lal Bazar, Srinagar.

E-mail: tariqqureshi317@gmail.com

INTRODUCTION: Diabetes is a metabolic disorder caused due to an absolute lack of insulin or due to insulin resistance $\&$ impaired insulin secretion..It is a major medical problem throughout the world. In India it is estimated that there are 37.77 million diabetics and will contribute to 57 million diabetics by the year 2025 (1).. It is the leading cause of blindness between ages $20 \& 74$ in US (2). Diabetes can affect nearly every part of ocular anatomy. Ophthalmic complications of diabetes include diabetic retinopathy, delayed corneal healing, glaucoma, poor pupillary dilation, corneal nerve palsies etc. Diabetes retinopathy is the most common and potentially most blinding of the complications and remains the number one cause of new blindness in most industrialized countries $(3,4)$.The researchers report that the prevalence of any diabetic retinopathy is $34.60 \%$. The prevalence of proliferative diabetic retinopathy is $6.96 \%$, diabetic macular edema is $6.81 \%$, and vision threatening diabetic retinopathy (VTDR) is $10.20 \%(5)$. Prevalence of blindness due to DR has been estimated to be $5 \%$ and may be as high as $8 \%$.

Among the risk factors of diabetic retinopathy, the duration of diabetes is probably the strongest predictor for development and progression of retinopathy (6). The other risk factors include poor glycemic control, nephropathy, pregnancy, hypertension, dyslipidemia, obesity and anemia. The protective effect of glycemic control has been confirmed by The Diabetes Control and Complications Trial (DCCT) (7) and The U.K. Prospective Diabetes Study (UKPDS) (8). Dyslipidemia is a known risk factor for diabetic renal disease, but the effect of serum lipids on diabetic retinopathy and macular edema is still under investigation (9-11).

MATERIALS AND METHODS: The present study was conducted in the Postgraduate Department of Ophthalmology, SMHS Hospital, Government Medical College, Srinagar, Kashmir. This was a cross sectional study.

Inclusion Criteria: All patients diagnosed with Proliferative and Nonproliferative Diabetic Retinopathy except those mentioned in the exclusion criteria's.

Exclusion criteria: Patients with

- Retinal venous obstruction (central retinal vein occlusion, branch retinal vein occlusion)

- Ocular Ischemic syndrome 
- Anemia

- Leukemia

- Coats' disease

- Sickle cell retinopathy

Total 100 cases were taken for the study and divided into two equal groups 'I' and 'II'.

Group I: Comprised of 50 patients (100 eyes) diagnosed with Nonproliferative Diabetic Retinopathy, with no eye having Proliferative Diabetic Retinopathy

Group II: Comprised of 50 patients (100 eyes) with atleast one of the eyes having Proliferative Diabetic Retinopathy

The patients were diagnosed on the basis of detailed history, comprehensive eye examination and appropriate investigations were done as and when required, which included:

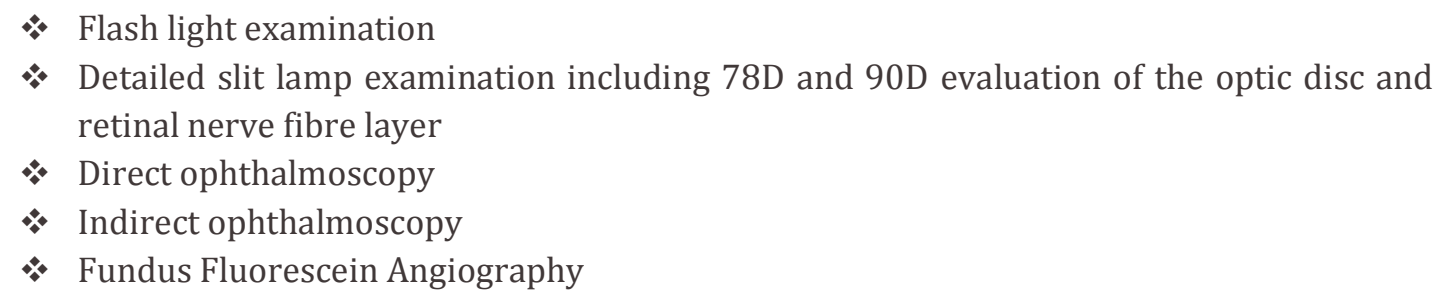

In both the groups, levels of HbA1c and serum lipids were evaluated and compared. Fasting blood samples were taken to assess lipid profiles, blood glucose and glycated haemoglobin (HbA1c) levels. All biochemical assays were carried out using a Hitachi 912 Autoanalyser. Serum cholesterol (CHOD-PAP method), serum triglycerides (GPO-PAP method) and highdensity lipoprotein (HDL)-cholesterol (direct method, polyethylene glycol-pretreated enzymes) were measured. LDL-cholesterol was calculated using the Friedewald formula. Glycated haemoglobin (HbA1c) was estimated by particle enhanced immunoturbidimetric test using the DiaSys Diagnostic Systems GmbH (Holzheim, Germany).

Statistical analysis: Data was expressed as mean \pm standard deviation (Mean \pm S.D.) and percentage. The data was analyzed and compared by using independent Student's t-test. Fischer's Exact test and Chi square test were also used.

RESULTS: The maximum numbers of patients were aged more than 40 years $(86.0 \%$ in Group I and $88.0 \%$ in Group II). The total number of Type2 diabetic patients (95 patients) outnumbered Type1 patients (5 patients). In Group I maximum number of patients 36 (72\%) were on Oral Hypoglycaemic Agents (OHA) whereas in Group II, 11 (22\%) were taking OHAs; maximum patients in Group II were on insulin (60\%). Coexisting hypertension was found in 38 patients (76\%) in Group I and 44 patients (88\%) in Group II. Family History of diabetes was found in $28 \%$ and $18 \%$ in Group I and Group II respectively. The number of cases with diabetic nephropathy was much higher in Group II (46\%) Table 2 demonstrates that the number of patients with diabetes of duration $\leq 5$ years was $56 \%$ in Group I \& $30 \%$ in Group II. There were 16 patients $(32 \%)$ in Group II with diabetes of duration more than 15 years whereas only 1 patient (2\%) of Group I had such a duration. 
In Group I, 22 eyes of the patients had visual acuity $<6 / 60$ whereas in Group II, the number was quitehigher( 53). In Group I, eyes of the patients with visual acuity $\geq 6 / 60$ was 78 whereas in Group II eyes with such visual acuity was 47 (Table 3).

Most of the eyes (50eyes, 50\%) of the patients in Group I had moderate NPDR, followed by very severe NPDR, severe NPDR \& mild NPDR with frequencies of 19\%, 18\% \& 13\% respectively. In Group II, maximum cases of the eyes (50eyes, 50\%) had early PDR, followed by High risk PDR (18\%) \& advanced PDR (5\%). NPDR could be seen in 27 eyes of the patients of Group II. Most of the eyes of the patients of Group I (43\%) \& Group II (54\%) had macular edema. (Table 4)

14 patients (28\%) had blood sugar fasting $<120 \mathrm{mg} / \mathrm{dl}$ whereas 6 patients $(12 \%)$ of the patients in Group II had such blood sugar fasting level. 16 patients (32\%) had blood sugar fasting level $\geq 150 \mathrm{mg} / \mathrm{dl}$ in Group I, whereas in Group II 29 patients (58\%) had blood sugar fasting level $\geq 150 \mathrm{mg} / \mathrm{dl}$. 18 patients (36\%) had HbA1c $<7 \%$ in Group I. However in Group II, only 5 patients $(10 \%)$ had HbA1c $<7 \%$. Only 18 patients $(36 \%)$ of Group I had HbA1c $>8 \%$ comparing it with Group II where 29 patients (58\%) had HbA1c >8\% (Table 5,).

Table 6 [6(a)-6(f)] shows the lipid profile of the studied cases. Table 6(a) shows that in Group I, $44 \%$ patients had total cholesterol between $150-<175 \mathrm{mg} / \mathrm{dl}$, whereas in Group II maximum number of patients $(36 \%$ ) had total cholesterol $>225 \mathrm{mg} / \mathrm{dl}$. In Table $6(\mathrm{~b}), 18$ patients (36\%) of Group I had LDL cholesterol between $150-<200 \mathrm{mg} / \mathrm{dl}$; however in Group II $44 \%$ patients had such a cholesterol level. Table 6(c) shows 16 patients (32\%) of Group II had HDL Cholesterol $<40 \mathrm{mg} / \mathrm{dl}$, whereas the number of patients of Group I belonging to such category was only 05 patients (10\%). The frequency of the patients with VLDL Cholesterol $>35 \mathrm{mg} / \mathrm{dl}$ in both the Groups I \& II were 54\% and 36\% respectively [Table 6(d)]. Table 6(e) illustrates that the number of patients with ratio of Total to HDL Cholesterol >4 in Group I was 27 (54\%) and in Group II the number was 37 patients (74\%). Table 6(f) demonstrates that in Group I, 26 patients (52\%) had triglyceride level $>150 \mathrm{mg} / \mathrm{dl}$ whereas in Group II such level of triglyceride was seen in 43 patients (86\%).

DISCUSSION: For many years, the role of hyperglycemia in the development of diabetic retinopathy has been investigated using epidemiologic studies and animal models. Initially, several clinical trials were conducted with the objective of comparing the evolution of the diabetic retinopathy in patients with tight blood glucose control versus standard management. However, it was the DCCT (7), the Stockholm Interventional Study (12), and the UKPDS (8) studies who evaluated the long-term benefit of improving glycemic control.. To prevent development and progression of diabetic retinopathy, a good glycemic control is very essential. HbA1c is a marker which can predict the glycemic control for last 3-4 months and patient can be counselled to have a strict glycemic control. Similarly altered lipid profile indirectly alters the glycemic control and progression of diabetic retinopathy.

Our study was conducted on 100 patients diagnosed with non proliferative diabetic retinopathy (NPDR) and proliferative diabetic retinopathy (PDR) and divided into two equal groups. Our study highlights several important findings.

In this study maximum numbers of patients were aged more than 60 years $32 \%$ and $68 \%$ in Group I and Group II respectively). Our finding is similar to the one reported by B LongoMbenza et al (13).

Type 2 diabetes was present in the majority of patients (95\%) whereas Type I diabetes was seen in five patients only. This difference is because of the fact that Type 2 diabetes mellitus is more common than Type 1 diabetes mellitus (14). Maximum number of patients $(36,72 \%)$ in 
Group I were on oral hypoglycaemic agents and in Group II maximum patients were on insulin $(30,60 \%)$.

Coexisting hypertension was found in most of the patients in the study $(76 \%$ and $88 \%$ in Groups I and II respectively). Renal disease was higher in patients of Group II (46\% patients) than Group I (6\%). Our study differs from the studies done by Klein R et al (15) and B LongoMbenza et al (13). However, studies done by Xia P et al (16) and Miller JW et al (17) have shown no significant benefits of renal protective drugs upon the progression of diabetic retinopathy.

Majority of the patients in Groups I had diabetes duration less than 5 years (56\%). However in Group II maximum patients (70\%) had diabetes duration more than 5 years. There were 16 patients (32\%) in Group II with diabetes duration more than 15 years whereas only 1 patient (2\%) of Group I had such a duration. The difference was statistically significant ( $p$-value $<0.0001$ ). Our findings were similar to the findings of B Longo-Mbenza et al (13), M.Rema et al (18) and Donald S. Fong et al (19) (Table 2)

Most of the eyes (50eyes, 50\%) of the patients in Group I had moderate NPDR, followed by very severe NPDR, severe NPDR \& mild NPDR with frequencies of 19\%, 18\% \& 13\% respectively whereas in Group II, maximum cases (50eyes, 50\%) had early PDR, followed by High risk PDR (18\%) \& advanced PDR (5\%). NPDR could be seen in 27 eyes of the patients of Group II (Table 4). Macular edema was present in 42\% right eyes \& $44 \%$ left eyes in Group I whereas in Group II it was seen in 54\% each right and left eyes.

In this study, 14 patients (28\%) had blood sugar fasting $<120 \mathrm{mg} / \mathrm{dl}$ whereas 6 patients $(12 \%)$ of the patients in Group II had such blood sugar fasting level. 16 patients (32\%) had blood sugar fasting level $\geq 150 \mathrm{mg} / \mathrm{dl}$ in Group I, whereas in Group II 29 patients (58\%) had blood sugar fasting level $\geq 150 \mathrm{mg} / \mathrm{dl}$. Wong TY et al (22) also found no uniform fasting blood sugar threshold for retinopathy across different populations and much higher prevalence of retinopathy at low fasting blood sugar levels.

In our study, 18 patients (36\%) had HbA1c $<7 \%$ in Group I. However in Group II, only 5 patients $(10 \%)$ had $\mathrm{HbA1c}<7 \%$. Only 18 patients (36\%) of Group I had HbA1c $>8 \%$ comparing it with Group II where 29 patients (58\%) had HbA1c $>8 \%$ (Table 5,). The difference between the two was highly significant ( $\mathrm{P}$ value $<0.001$ ). These findings are similar to those observed by Klein R et al (23), Davis et al (24), B Longo-Mbenza et al (13). Conversely, literature reports have shown compelling evidence that diabetic microangiopathies can be reduced by tight glycemic control (25).

Studies have looked at the association of serum lipids with microvascular complications of diabetes such as DR and the available results are conflicting. Dornan et al. (26) first showed in a landmark study the association of LDL-cholesterol in subjects with DR. This was further substantiated by Miccoli et al (27). In our study, on comparing the LDL cholesterol levels of the two groups, it was found the two were statistically significant (p-value 0.031 ). The progression to proliferative retinopathy was also shown to be related to serum triglycerides and LDL by Lloyd CE et al (28). In the Wisconsin Epidemiology Study of Diabetic Retinopathy (WESDR), Klein et al. (29) reported an association of unadjusted serum cholesterol with severity of hard exudates in the macula. Data from the ETDRS have demonstrated the association of total cholesterol and LDL-cholesterol with the onset as well as severity of retinal hard exudates (30). Although retinal hard exudates usually accompanied diabetic macular edema, increasing amounts of exudates appeared to be independently associated with an increased risk of visual impairment in this study. 
Additionally, we reported an association between serum triglyceride concentrations and DR in subjects; the statistical difference was significant ( $p$-value $<0.041$ ). However, on analysing the levels of total cholesterol in Groups I and II, it was found the difference between the two was not statistically significant ( $p$-value 0.152 ). The former result is consistent with the study by van Leiden et al. (31), who showed an association between unadjusted triglyceride levels and DR in subjects with Type 2 diabetes. The report by the DCCT/EDIC group has also shown that the severity of retinopathy was associated with serum triglycerides after adjusting for gender in subjects with Type 1 diabetes (32). Findings of the EURODIAB IDDM Complications study group show that cholesterol is related to all levels of retinopathy and that triglycerides are associated with moderately severe non-proliferative and proliferative retinopathy (33). However, Larsson et al. (34) reported no association between serum triglycerides and degree of retinopathy in subjects with Type 1 diabetes. In our study there was an overall association of DR with triglycerides.

In our study on comparing the HDL levels of the two groups, it was found the difference between the two was statistically significant (p-value 0.022). B Longo-Mbenza et al (13) also reported that low HDL-cholesterol is significantly associated with the presence and the severity of diabetic retinopathy while Kordonouri et al (35) showed HDL cholesterol to be the most important variable related to the development of retinal lesions in children with Type 1 diabetes mellitus.

For the outcome of progression of diabetic retinopathy there were significant associations with total-to-HDL cholesterol ratio (p-value 0.019). Biljana Miljanovic et al (36) also found significant association of total cholesterol-to-HDL ratio and triglycerides with PDR patients. On comparing the VLDL Cholesterol of the two groups, it was established that the difference between the two insignificant (p-value 0.060). Table 6: 6(a)-6(f),

Our understanding of the pathophysiology of the diabetes is increasing as new biochemical pathways are identified. Our ability to diagnosis and classify retinopathy is also improving. In addition, the treatment of diabetic retinopathy involves not just laser photocoagulation and vitrectomy surgeries but now also includes control of blood glucose, hypertension, and serum lipids. In the near future, clinical trials of several pharmacologic agents may lead to the introduction of additional treatments and reduction in the frequency of visual loss.

CONCLUSION: In all diabetic patients increased diabetes duration $(10.54 \pm 7.21$, p-value $<0.001)$, poor control of HbA1c $(8.4 \pm 1.6$, p-value <0.001), low HDL (43.3 \pm 9.3 , p-value 0.022$)$, higher triglycerides (183.8 \pm 58.3 , p-value $<0.041) \&$ LDL $(163.1 \pm 56.3$, p-value 0.031$)$ and raised total cholesterol to HDL ratio $(4.9 \pm 1.4$, p-value 0.019$)$ are significantly associated with the patients having proliferative diabetic retinopathy.

Thus early diagnosis, diabetes monitoring, urgent and efficient diabetes care, together with rigorous lipid control, will decrease the risk of progression to proliferative diabetic retinopathy, an important cause of vision loss.

\section{REFERENCES:}

1. King H, Aubert RE, Herman WH, Global burden of diabetes 1995-2025, Diabetes Care 1998; 21: 1414-31.

2. Alvin C Powers- Diabtes Mellitus In: Kasper DL, Braunwald E, Fauci As et al, Harrison's Principle of Internal Medicine, McGraw Hill (16 ${ }^{\text {th }}$ edition, Vol II) 2152-2163. 
3. Aiello LM, Cavallerano JD, Aiello LP, Bursell SE. Diabetic retinopathy. In: Guyer DR, Yannuzzi LA, Chang S, et al, eds. Retina Vitreous Macula. Vol 2. 1999:316-44.

4. Benson WE, Tasman W, Duane TD. Diabetes mellitus and the eye. In: Duane's Clinical Ophthalmology. Vol 3. 1994.

5. Joanne W.Y. Yau, Sophie L. Rogers, Ryo Kawasaki, Ecosse L. Lamoureux, Jonathan W. Kowalski, TokeBek et al. Global Prevalence and Major Risk Factors of Diabetic Retinopathy. Diabetes Care. Vol. 35 No.3:556-564, 2012.

6. Klein R, Klein B. Epidemiology of proliferative diabetic retinopathy. Diabetes Care. 1992; 15:1875-91.

7. The Diabetes Control and Complications Trial Research Group. (1993). "The effect of intensive treatment of diabetes on the development and progression of long-term complications in insulin-dependent diabetes mellitus". New England Journal of Medicine.329 (14): 977-86.

8. Intensive blood-glucose control with sulphonylureas or insulin compared with conventional treatment and risk of complications in patients with type 2 diabetes. UKPDS 33. The Lancet, Volume 352, Issue 9131, Pages 837 - 853, 12 September 1998.

9. Larsen M, Hommel E, Parving HH, Lund-Anderson H: Protective effect of captopril on the blood-retina barrier in normotensive insulin-dependent diabetic patients with nephropathy and background retinopathy. Graefes Arch ClinExpOphthalmol 228:505509,1990

10. Ravid M, Brosh D, Ravid-Safran D, Levy Z, Rachmani R: Main riskfactors for nephropathy in type 2 diabetes mellitus are plasma cholesterol levels, mean blood pressure, and hyperglycemia. Arch Intern Med 158:998-1004, 1998

11. Chowdhury TA, Hopkins D, Dodson PM, Vafidis GC: The role of serum lipids in exudative diabetic maculopathy: is there a place for lipid lowering therapy? Eye 16:689-693, 2002

12. Reichard P, Nilsson B, Rosenqvist U. Retardation of the development of microvascular complications after long-term intensified insulin treatment: the Stockholm Diabetes Intervention Study. N Engl J Med 1993; 329: 304-9.

13. B Longo-Mbenza, MM Muaka, G Mbenza et al. Risk factors of poor control of HBA1c and diabetic retinopathy: Paradox with insulin therapy and high values of HDL in African diabetic patients. Int J Diabetes \& Metabolism (2008) 16: 69-78

14. WHO Diabetes: $\quad$ Factsheet $\mathrm{N}^{\circ} 312$ September 2012http://www.who.int/mediacentre/factsheets/fs312/en/.

15. Klein R, Klein BEK, Moss SE, Cruickshanks KJ: The Wisconsin Epidemiologic Study of Diabetic Retinopathy. V. Proteinuria and retinopathy in a population of diabetic persons diagnosed prior to 30 years of age. In Diabetic Renal-Retinal Syndrome 3. Freidman EA, L'Esperance FA, Eds. Orlando, FL, Grune\& Stratton, 1986

16. Xia P, Aiello LP, Ishii H, Jiang ZY, Park DJ, Robinson GS, Takagi H, Newsome WP, Jirousek MR, King GL: Characterization of vascular endothelial growth factor's effect on the activation of protein kinase $\mathrm{C}$, its isoforms, and endothelial cell growth. J Clin Invest 98:2018-2026, 1996

17. Miller JW, Adamis AP, Aiello LP: Vascular endothelial growth factor in ocular neovascularization andproliferative diabetic retinopathy. DiabeteMetab Rev 13:37-50, 1997 
18. M. Rema, B. K. Srivastava, B. Anitha, R. Deepa and V. Mohan. Association of serum lipids with diabetic retinopathy in urban South Indians-the Chennai Urban Rural Epidemiology Study (CURES) Eye Study -2. DOI: 10.1111/j.1464-5491.2006.01890.

19. Donald S. Fong, Lloyd Aiello, Thomas W. Gardner et al. Retinopathy in Diabetes. doi: 10.2337/diacare.27.2007.S84 Diabetes Care January 2004 vol. 27.

20. Kunikata $H$, Nakagawa $Y$, Tamai M Evaluation of visual function and prognosis for patients with proliferativediabetic retinopathy with the low vision evaluator. Tohoku I Exp Med. 2004 Nov; 204(3):229-36.

21. Monica Rodriguez-Fontal, John B. Kerrison, D. Virgil Alfaro et al. Metabolic Control and Diabetic Retinopathy. Current Diabetes Reviews, 2009, 5, 3-7

22. Wong TY, Liew G, Tapp RJ, Schmidt MI et al. Relation between fasting glucose and retinopathy for diagnosis of diabetes: three population-based cross-sectional studies. Lancet 2008;371:736-743

23. Klein R, Klein B, Moss S, et al. The Wisconsin epidemiologic study of diabetic retinopathy. Ten-year incidence and progression of diabetic retinopathy. Arch Ophthalmol. 1994; 112:1217-28.

24. Davis MD, Fisher MR, Gangnon RE, et al. Risk factors for high-risk proliferative diabetic retinopathy and severe visual loss: Early Treatment Diabetic Retinopathy Study Report 18. Invest Ophthalmol Vis Sci. 1998;39:233-252.

25. UK Prospective Diabetes Study (UKPDS). Intensive Blood-glucose Control with sulphonylureas or insulin compared with conventional treatment and risk of complications in patients with type 2 diabetes: UKPDS 33. Lancet 1998; 352:837-853.

26. Dornan TL, Carter RD, Bron AJ, Turner RC, Mann JI. Low density lipoprotein cholesterol: an association with the severity of diabetic retinopathy. Diabetologia1982; 22: 167-170.

27. Miccoli R, Odello G, Giampetro O, Marchetti P, Cristofani R, Penno G, et al. Circulating lipid levels and severity of diabetic retinopathy in type I diabetes mellitus. Ophthalmic Res 1987; 19:52-6.

28. Lloyd CE, Klein R, Maser RE, Kuller LH, Becker DJ, Orchard TJ. The progression of retinopathy over 2 years: the Pittsburgh Epidemiology of Diabetes Complications (EDC) Study. J Diabetes \& Its Complications 1995; 9:140-8.

29. Klein BE, Klein R, Moss SE. Is serum cholesterol associated with progression of diabetic retinopathy or macular edema in persons with younger-onset diabetes of long duration? Am J Ophthalmol1999; 128: 652-654.

30. Chew EY, Klein ML, Ferris FL 3rd, Remaley NA, Murphy RP, Chantry K et al. Association of elevated serum lipid levels with retinal hard exudate in diabetic retinopathy. Early Treatment Diabetic Retinopathy Study (ETDRS) Report 22. Arch Ophthalmol1996;114: 1079-1084.

31. Van Leiden HA, Dekker JM, Moll AC, Nijpels G, Heine RJ, Bouter LM et al. Blood pressure, lipids, and obesity are associated with retinopathy: the Hoorn study. Diabetes Care 2002; 25: 1320-1325.

32. Lyons TJ, Jenkins AJ, Zheng D, Lackland DT, McGee D, Garvey WT et al. Diabetic retinopathy and serum lipoprotein subclasses in the DCCT/EDIC cohort. Invest Ophthalmol Vis Sci2004; 45: 910- 918.

33. Sjolie AK, Stephenson J, Aldington S, Kohner E, Janka H, Stevens L, et al. Retinopathy and vision loss in insulin-dependent diabetes in Europe. The EURODIAB IDDM Complications Study. Ophthalmology 1997; 104:252-60. 
34. Larsson LI, Alm A, Lithner F, Dahlen G, Bergstrom R. The association of hyperlipidemia with retinopathy in diabetic patients aged 15-50 years in the county of Umea. ActaOphthalmolScand1999; 77: 585-591.

35. Kordonouri O, Danne T, Hopfenmuller W, Enders I, Hovener G, Weber B. Lipid profiles and blood pressure: are they risk factors for the development of early background retinopathy and incipient nephropathy in children with insulin-dependent diabetes mellitus? ActaPaediatrica 1996, 85:43-8.

36. BiljanaMiljanovic, Robert J. Glynn, David M. Nathan,JoAnnE.Manson and Debra A. Schaumberg. A Prospective Study of Serum Lipids and Risk of Diabetic Macular Edema in Type 1 Diabetes.Diabetes,Vol. 53,04: 883-92.

37. BiljanaMiljanovic, Robert J. Glynn, David M. Nathan,JoAnnE.Manson and Debra A. Schaumberg. A Prospective Study of Serum Lipids and Risk of Diabetic Macular Edema in Type 1 Diabetes.Diabetes,Vol. 53,04: 883-92.

Table-1 Clinical and biochemical characteristics of the study groups.

\begin{tabular}{|l|l|l|l|}
\hline Variable & NPDR & PDR & P-value \\
\hline Age (years) & $54.1 \pm 10.8$ & $57.1 \pm 14.0$ & 0.234 (NS) \\
\hline Duration of diabetes (yrs) & $6.0 \pm 3.0$ & $10.5 \pm 7.0$ & $<0.001$ (Sig) \\
\hline Fasting Blood Glucose (mg/dl) & $151.2 \pm 43.5$ & $166.6 \pm 37.3)$ & $0.06 \mathrm{~s} 2$ (NS) \\
\hline HbA $_{\mathbf{1 C}}$ (\%) & $7.2 \pm 1.3$ & $8.4 \pm 1.6$ & $<0.001$ (Sig) \\
\hline Serum-Cholesterol (mg/dl) & $199.7 \pm 56.6$ & $217.3 \pm 65.0$ & $0.152(\mathrm{NS})$ \\
\hline HDL-Cholesterol (mg/dl) & $47.2 \pm 7.4$ & $43.3 \pm 9.3$ & $0.022(\mathrm{Sig})$ \\
\hline LDL-Cholesterol (mg/dl) & $140.5 .1 \pm 46.2$ & $163.1 \pm 56.3$ & $0.031(\mathrm{Sig})$ \\
\hline VLDL- Cholesterol (mg/dl) & $41.4 \pm 22.6$ & $34.7 \pm 10.6$ & 0.060 (NS) \\
\hline Serum -triglyceride (mg/d) & $142.8 \pm 19.6$ & $183.8 \pm 58.3$ & $0.041(\mathrm{Sig})$ \\
\hline Total-Cholesterol/HDL Ratio & $4.3 \pm 1.1$ & $4.9 \pm 1.4$ & 0.019 (Sig) \\
\hline
\end{tabular}


Table 2 : Distribution of the Studied Subjects by duration of diabetes

\begin{tabular}{|c|c|c|c|c|c|c|c|}
\hline \multirow{2}{*}{ Duration (yrs) } & \multicolumn{2}{|c|}{ NPDR } & \multicolumn{2}{|c|}{ PDR } & \multicolumn{2}{|c|}{ Total } & \multirow[t]{2}{*}{ P value } \\
\hline & $\mathrm{n}$ & $\%$ & $\mathrm{n}$ & $\%$ & $\mathrm{n}$ & $\%$ & \\
\hline$\leq 5$ & 28 & 56.0 & 15 & 30.0 & 43 & 43.0 & \multirow{5}{*}{$<0.001$ (Sig) } \\
\hline $6-15$ & 21 & 42.0 & 19 & 38.0 & 40 & 40.0 & \\
\hline $16-25$ & 01 & 02.0 & 12 & 24.0 & 13 & 13.0 & \\
\hline$>25$ & - & - & 04 & 08.0 & 04 & 04.0 & \\
\hline $\begin{array}{l}\text { Mean } \pm \text { SD } \\
(\text { Min,Max) }\end{array}$ & \multicolumn{2}{|c|}{$6.15 \pm 3.08(0.5,14.0)$} & \multicolumn{2}{|c|}{$10.54 \pm 7.21(0.25,30.0)$} & & & \\
\hline
\end{tabular}

Table 3: Visual Acuity in the studied cases

\begin{tabular}{|c|c|c|c|c|c|c|c|c|c|}
\hline \multirow{3}{*}{$\begin{array}{l}\text { Visual } \\
\text { acuity }\end{array}$} & \multicolumn{4}{|l|}{ Group I } & \multicolumn{4}{|l|}{ Group II } & \multirow{3}{*}{$\begin{array}{l}P \\
\text { value }\end{array}$} \\
\hline & \multicolumn{2}{|l|}{ Right Eye } & \multicolumn{2}{|l|}{ Left Eye } & \multicolumn{2}{|l|}{ Right Eye } & \multicolumn{2}{|l|}{ Left Eye } & \\
\hline & $\begin{array}{l}\text { Frequenc } \\
\mathrm{y}\end{array}$ & \%age & $\begin{array}{l}\text { Frequenc } \\
\mathrm{y}\end{array}$ & \%age & $\begin{array}{l}\text { Frequenc } \\
\mathrm{y}\end{array}$ & \%age & $\begin{array}{l}\text { Frequenc } \\
\mathrm{y}\end{array}$ & $\begin{array}{l}\text { \%ag } \\
\text { e }\end{array}$ & \\
\hline $\begin{array}{l}\text { HM, } \\
\text { PL, PR }\end{array}$ & 02 & 04.0 & 01 & 02.0 & 03 & 06.0 & 03 & 06.0 & \\
\hline $\begin{array}{l}\text { CF } 1- \\
6 \mathrm{~m}\end{array}$ & 07 & 14.0 & 12 & 24.0 & 21 & 42.0 & 26 & 52.0 & \\
\hline $\begin{array}{l}6 / 60- \\
6 / 36\end{array}$ & 19 & 38.0 & 16 & 32.0 & 16 & 32.0 & 15 & 30.0 & $\begin{array}{l}<0.00 \\
1\end{array}$ \\
\hline $\begin{array}{l}6 / 24- \\
6 / 6\end{array}$ & 22 & 44.0 & 21 & 42.0 & 10 & 20.0 & 06 & 12.0 & (Sig) \\
\hline $\begin{array}{l}\text { TOTA } \\
\text { L }\end{array}$ & 50 & $\begin{array}{l}100 . \\
0\end{array}$ & 50 & $\begin{array}{l}100 . \\
0\end{array}$ & 50 & $\begin{array}{l}100 . \\
0\end{array}$ & 50 & 100 & \\
\hline
\end{tabular}


Table 4: Distribution of studied cases by type of diabetic retinopathy .

\begin{tabular}{|c|c|c|c|c|c|c|c|c|}
\hline \multirow[t]{3}{*}{ Type of DR } & \multicolumn{4}{|l|}{ Group I } & \multicolumn{4}{|l|}{ Group II } \\
\hline & \multicolumn{2}{|l|}{ Right Eye } & \multicolumn{2}{|l|}{ Left Eye } & \multicolumn{2}{|l|}{ Right Eye } & \multicolumn{2}{|l|}{ Left Eye } \\
\hline & Frequency & \%age & Frequency & \%age & Frequency & \%age & Frequency & \%age \\
\hline \multicolumn{9}{|l|}{ NPDR } \\
\hline Mild NPDR & 08 & 16.0 & 05 & 10.0 & - & - & - & - \\
\hline Moderate NPDR & 21 & 42.0 & 29 & 58.0 & 07 & 14.0 & 03 & 6.0 \\
\hline Severe NPPR & 09 & 18.0 & 09 & 18.0 & 06 & 12.0 & 04 & 8.0 \\
\hline Very Severe NPDR & 12 & 24.0 & 07 & 14.0 & 05 & 10.0 & 02 & 4.0 \\
\hline \multicolumn{9}{|l|}{ PDR } \\
\hline Early PDR & - & - & - & - & 23 & 46.0 & 27 & 54.0 \\
\hline PDR - HRC & - & - & - & - & 06 & 12.0 & 12 & 24.0 \\
\hline Advanced PDR & - & - & - & - & 03 & 6.0 & 02 & 4.0 \\
\hline TOTAL & 50 & 100.0 & 50 & 100.0 & 50 & 100.0 & 50 & 100.0 \\
\hline
\end{tabular}

\begin{tabular}{|c|c|c|c|c|c|c|c|}
\hline \multirow{2}{*}{ HbA1c (\%) } & \multicolumn{2}{|c|}{ NPDR } & \multicolumn{2}{|c|}{ PDR } & \multicolumn{2}{|c|}{ Total } & \multirow[t]{2}{*}{ P value } \\
\hline & $\mathrm{n}$ & $\%$ & $\mathrm{n}$ & $\%$ & $\mathrm{n}$ & $\%$ & \\
\hline$<6.0$ & 03 & 06.0 & 03 & 6.0 & 06 & 06.0 & \multirow{6}{*}{$<0.001$ (Sig) } \\
\hline $6.0-<7.0$ & 18 & 36.0 & 02 & 4.0 & 20 & 20.0 & \\
\hline $7.0-<8.0$ & 20 & 40.0 & 16 & 32.0 & 36 & 36.0 & \\
\hline $8.0-<9.0$ & 06 & 12.0 & 14 & 28.0 & 20 & 20.0 & \\
\hline$\geq 9.0$ & 03 & 06.0 & 15 & 30.0 & 18 & 18.0 & \\
\hline $\begin{array}{l}\text { Mean } \pm \text { SD } \\
(\text { Max,Min) }\end{array}$ & \multicolumn{2}{|c|}{$\begin{array}{l}(7.2 \pm 1.3) \\
(4.2,11.0)\end{array}$} & \multicolumn{2}{|c|}{$(8.4 \pm 1.6)(6.0,13.3)$} & & & \\
\hline
\end{tabular}


Table 6 : Lipid Profile of the Studied Cases

Table 6 (a): Level of Total Cholesterol in the two Studied Groups

\begin{tabular}{|c|c|c|c|c|c|c|c|}
\hline \multirow{2}{*}{$\begin{array}{l}\text { Total } \\
\text { Cholesterol } \\
\text { (mg/dl) }\end{array}$} & \multicolumn{2}{|c|}{ NPDR } & \multicolumn{2}{|c|}{ PDR } & \multicolumn{2}{|c|}{ Total } & \multirow[t]{2}{*}{$P$ value } \\
\hline & $\mathrm{n}$ & $\%$ & $\mathrm{n}$ & $\%$ & $\mathrm{n}$ & $\%$ & \\
\hline$<150$ & 01 & 2.0 & 03 & 6.0 & 04 & 04.0 & \multirow{6}{*}{$0.152(\mathrm{NS})$} \\
\hline $150-<175$ & 22 & 44.0 & 11 & 22.0 & 33 & 33.0 & \\
\hline $175-<200$ & 13 & 26.0 & 14 & 28.0 & 27 & 27.0 & \\
\hline $200-<225$ & 02 & 4.0 & 04 & 8.0 & 06 & 06.0 & \\
\hline$\geq 225$ & 12 & 24.0 & 18 & 36.0 & 30 & 30.0 & \\
\hline $\begin{array}{l}\text { Mean } \pm \text { SD } \\
(\text { Max,Min) }\end{array}$ & \multicolumn{2}{|c|}{$\begin{array}{l}(199.7 \pm 56.6) \\
(148.0,380.0)\end{array}$} & \multicolumn{2}{|c|}{$\begin{array}{l}(217.3 \pm 65.0) \\
(128.0,390.0)\end{array}$} & & & \\
\hline
\end{tabular}

\begin{tabular}{|c|c|c|c|c|c|c|c|}
\hline \multirow{2}{*}{$\begin{array}{l}\text { LDL } \\
\text { Cholesterol } \\
(\mathrm{mg} / \mathrm{dl})\end{array}$} & \multicolumn{2}{|c|}{ NPDR } & \multicolumn{2}{|c|}{ PDR } & \multicolumn{2}{|c|}{ Total } & \multirow[t]{2}{*}{ P value } \\
\hline & $\mathrm{n}$ & $\%$ & $\mathrm{n}$ & $\%$ & $\mathrm{n}$ & $\%$ & \\
\hline$<50$ & 02 & 4.0 & 01 & 2.0 & 03 & 03.0 & \multirow{6}{*}{0.031 (Sig) } \\
\hline $50-<100$ & 07 & 14.0 & 09 & 18.0 & 16 & 16.0 & \\
\hline $100-<150$ & 20 & 40.0 & 10 & 20.0 & 30 & 30.0 & \\
\hline $150-<200$ & 18 & 36.0 & 22 & 44.0 & 40 & 40.0 & \\
\hline$\geq 200$ & 03 & 6.0 & 08 & 16.0 & 11 & 11.0 & \\
\hline $\begin{array}{l}\text { Mean } \pm \text { SD } \\
(\text { Max,Min) }\end{array}$ & \multicolumn{2}{|c|}{$(140.5 .1 \pm 46.2)(62.0,271.0)$} & \multicolumn{2}{|c|}{$(163.1 \pm 56.3)(65.0,280.0)$} & & & \\
\hline
\end{tabular}

Table 6 (d): Level of VLDL Cholesterol in the two Studied Groups 
ORIGINAL ARTICLE

\begin{tabular}{|c|c|c|c|c|c|c|c|}
\hline \multirow{2}{*}{$\begin{array}{l}\text { VLDL } \\
\text { Cholesterol } \\
\text { (mg/dl) }\end{array}$} & \multicolumn{2}{|c|}{ NPDR } & \multicolumn{2}{|c|}{ PDR } & \multicolumn{2}{|c|}{ Total } & \multirow[t]{2}{*}{ P value } \\
\hline & $\mathrm{n}$ & $\%$ & $\mathrm{n}$ & $\%$ & $\mathrm{n}$ & $\%$ & \\
\hline$<25$ & 03 & 6.0 & 08 & 16.0 & 12 & 12.0 & \multirow{6}{*}{$0.060(\mathrm{NS})$} \\
\hline $25-<30$ & 08 & 16.0 & 04 & 8.0 & 09 & 09.0 & \\
\hline $30-<35$ & 12 & 24.0 & 20 & 40.0 & 22 & 22.0 & \\
\hline $35-<40$ & 04 & 8.0 & 08 & 16.0 & 32 & 32.0 & \\
\hline$\geq 40$ & 23 & 46.0 & 10 & 20.0 & 25 & 25.0 & \\
\hline $\begin{array}{l}\text { Mean } \pm \text { SD } \\
(\text { Max,Min) }\end{array}$ & \multicolumn{2}{|c|}{$\begin{array}{l}(41.4 \pm 22.6) \\
(19.0,171.0)\end{array}$} & \multicolumn{2}{|c|}{$\begin{array}{l}(34.7 \pm 10.6) \\
(16.0,67.0)\end{array}$} & & & \\
\hline
\end{tabular}

\begin{tabular}{|c|c|c|c|c|c|c|c|}
\hline \multicolumn{8}{|c|}{ Table 6 (e): Level of Total-to-HDL Cholesterol Ratio in the two Studied Groups } \\
\hline \multirow{2}{*}{$\begin{array}{l}\text { Total-to- } \\
\text { HDL } \\
\text { Cholesterol } \\
\text { Ratio }\end{array}$} & \multicolumn{2}{|c|}{ NPDR } & \multicolumn{2}{|c|}{ PDR } & \multicolumn{2}{|c|}{ Total } & \multirow[t]{2}{*}{$P$ value } \\
\hline & $\mathrm{n}$ & $\%$ & $\mathrm{n}$ & $\%$ & $\mathrm{n}$ & $\%$ & \\
\hline$<3$ & 04 & 8.0 & 03 & 6.0 & 07 & 07.0 & \multirow{7}{*}{0.019 (Sig) } \\
\hline $3-<3.5$ & 06 & 12.0 & 02 & 4.0 & 08 & 08.0 & \\
\hline $3.5-<4$ & 13 & 26.0 & 08 & 16.0 & 21 & 21.0 & \\
\hline $4-<4.5$ & 10 & 20.0 & 08 & 16.0 & 18 & 18.0 & \\
\hline $4.5-<5$ & 07 & 14.0 & 12 & 24.0 & 19 & 19.0 & \\
\hline$\geq 5$ & 10 & 20.0 & 17 & 34.0 & 27 & 27.0 & \\
\hline $\begin{array}{l}\text { Mean } \pm \text { SD } \\
\text { (Max,Min) }\end{array}$ & \multicolumn{2}{|c|}{$(4.3 \pm 1.1)(2.5,7.3)$} & \multicolumn{2}{|c|}{$(4.9 \pm 1.4)(2.2,10.2)$} & & & \\
\hline
\end{tabular}

Table 6 (f): Level of Triglycerides in the two Studied Groups 
ORIGINAL ARTICLE

\begin{tabular}{|c|c|c|c|c|c|c|c|}
\hline \multirow{2}{*}{$\begin{array}{l}\text { Triglycerides } \\
\text { (mg/dl) }\end{array}$} & \multicolumn{2}{|c|}{ NPDR } & \multicolumn{2}{|c|}{ PDR } & \multicolumn{2}{|c|}{ Total } & P value \\
\hline & $\mathrm{n}$ & $\%$ & $\mathrm{n}$ & $\%$ & $\mathrm{n}$ & $\%$ & \multirow{7}{*}{$<0.041$ (Sig) } \\
\hline$<50$ & 02 & 4.0 & 01 & 2.0 & 03 & 03.0 & \\
\hline $50-<100$ & 03 & 6.0 & 02 & 4.0 & 05 & 05.0 & \\
\hline $100-<150$ & 19 & 38.0 & 04 & 8.0 & 23 & 23.0 & \\
\hline $150-<200$ & 22 & 44.0 & 22 & 44.0 & 44 & 44.0 & \\
\hline$\geq 200$ & 04 & 8.0 & 21 & 42.0 & 25 & 25.0 & \\
\hline $\begin{array}{l}\text { Mean } \pm \text { SD } \\
(\text { Max,Min) }\end{array}$ & \multicolumn{2}{|c|}{$\begin{array}{l}(142.8 \pm 19.6) \\
(95.0,171.0)\end{array}$} & \multicolumn{2}{|c|}{$\begin{array}{l}(183.8 \pm 58.3) \\
(87.0,302.0)\end{array}$} & & & \\
\hline
\end{tabular}

